\title{
Development of a membrane adsorber based capture step for the purification of yellow fever virus
}

\author{
Tânia P. Pato ${ }^{a, c}$, Marta Cristina O. Souza ${ }^{a}$, Andréa N.M.R. Silva ${ }^{a}$, Renata C. Pereira ${ }^{a}$, \\ Marlon V. Silva ${ }^{a}$, Elena Caride ${ }^{a}$, Luciane P. Gaspar ${ }^{\mathrm{a}}$, Marcos S. Freire ${ }^{\mathrm{a}}$, Leda R. Castilho ${ }^{\mathrm{b}, \mathrm{c}, *}$ \\ a Oswaldo Cruz Foundation (FIOCRUZ), Bio-Manguinhos, Avenida Brasil 4365, 21045-900 Rio de Janeiro/RJ, Brazil \\ ${ }^{\mathrm{b}}$ Federal University of Rio de Janeiro, COPPE, Cell Culture Engineering Laboratory, Cx. Postal 68502, 21941-972 Rio de Janeiro/RJ, Brazil

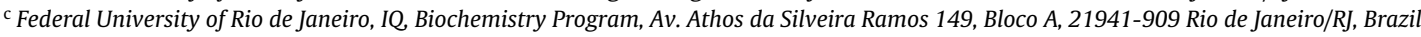

\section{A R T I C L E I N F O}

\section{Article history:}

Available online 11 March 2014

\begin{abstract}
A B S T R A C T
Yellow fever (YF) is an endemic disease in some tropical areas of South America and Africa that presents lethality rate between 20 and $50 \%$. There is no specific treatment and to control this disease a highly effective live-attenuated egg based vaccine is widely used for travelers and residents of areas where YF is endemic. However, recent reports of rare, sometimes fatal, adverse events post-vaccination have raised concerns. In order to increase safety records, alternative strategies should be considered, such as developing a new inactivated vaccine using a cell culture based technology, capable of meeting the demands in cases of epidemic. With this goal, the production of YF virus in Vero cells grown on microcarriers and its subsequent purification by chromatographic techniques was studied. In this work we investigate the capture step of the purification process of the YF virus. At first, virus stability was studied over a wide $\mathrm{pH}$ range, showing best results for the alkaline region. Considering this result and the pI of the envelope protein previously determined in silico, a strong anion exchanger was considered most suitable. Due to the easy scalability, simplicity to handle, absence of diffusional limitations and suitability for virus handling of membrane adsorbers, a $\mathrm{Q}$ membrane was evaluated. The amount of antigen adsorbed onto the membrane was investigated within the $\mathrm{pH}$ range for virus stability, and the best $\mathrm{pH}$ for virus adsorption was considered to be 8.5. Finally, studies on gradient and step elution allowed to determine the most adequate salt concentration for washing $(0.15 \mathrm{M})$ and virus elution $(0.30 \mathrm{M})$. Under these operating conditions, it was shown that this capture step is quite efficient, showing high product recovery $(93.2 \pm 30.3 \%)$ and efficient DNA clearance $(0.9 \pm 0.3 \mathrm{ng} /$ dose $)$.
\end{abstract}

(c) 2014 Elsevier Ltd. All rights reserved.

\section{Introduction}

Yellow fever (YF) is a viral disease, endemic to tropical regions of Africa and South America, characterized by fever, nausea, vomiting, epigastric pain, hepatitis with jaundice, renal failure, hemorrhage, and shock. The fatality rate often is between 20 and $50 \%$ and there are no specific therapies. It is estimated that 200,000 cases occur annually in Africa, South America and Central America [1,2]. The virus is transmitted to and between humans via the bite of infected insects of the family Culicidae, of the genera Haemagogus (in wild areas) and Aedes (in urban areas). The causative agent, YF virus, has

\footnotetext{
* Corresponding author at: Federal University of Rio de Janeiro, COPPE, Cell Culture Engineering Laboratory, Cx. Postal 68502, 21941-972 Rio de Janeiro/RJ, Brazil. Tel.: +552125628336.

E-mail address: leda@peq.coppe.ufrj.br (L.R. Castilho).
}

a single-stranded RNA and belongs to the Flavivirus genus of the Flaviviridae family. The virus particles are about $50 \mathrm{~nm}$ in size [3,4].

To control this disease a highly effective live-attenuated vaccine is available since the 1930s, manufactured in embryonated eggs, based on the virus substrains 17 DD and 17D-204. This vaccine is widely used for travelers and residents of areas in which YF is endemic. An acceptable safety profile has been well established during these decades, considering the application of more than 500 million doses. However, reports of rare, but serious adverse events post-vaccination have raised concerns $[4,5]$. This category of adverse event, named vaccine-associated viscerotropic disease, was first described in Brazil in 1999 and was shown to occur with a frequency of 3-4 per million doses administered and a case fatality of $60 \%$ [2].

In order to increase safety records, alternative strategies have been considered, one of them aiming at developing a new inactivated vaccine, that could potentially be used in immunosuppressed 
individuals, persons with allergies to egg proteins, infants under 9 months of age, and even pregnant and nursing women [1].

The state vaccine producer Bio-Manguinhos/Oswaldo Cruz Foundation (Rio de Janeiro, Brazil) is the world's largest producer of attenuated yellow fever vaccine. In recent years, Bio-Manguinhos started developing an inactivated vaccine using non-egg based technology and adopting chromatographic steps to achieve high virus purification.

In recent decades significant advances in the production of virus using animal cell culture in large-scale bioreactors occurred. Comparatively less effort has been dedicated to the downstream process, which currently constitutes a major bottleneck in the production of biologicals. In order to economically manufacture high-quality viral vaccines, with high antigen concentration and low levels of impurities such as DNA and host cell protein (HCP), meeting the specifications required by regulatory agencies, the development of a simple and efficient method for purification of virus is crucial [6-8].

Widely used traditional procedures for virus purification, such as cycles of differential centrifugation, ultracentrifugation and density gradient centrifugation are almost impracticable for largescale biomanufacturing. Therefore, in recent years chromatography has been intensively investigated as a method for efficient virus purification. However, conventional chromatography using porous resins packed in fixed beds is inappropriate for purification of large biomolecules such as virus particles, due to the small pore sizes and high shearing forces that develop inside the columns [7,9].

Replacement of resins by highly porous chromatographic supports, such as membranes and monoliths, overcomes many of the limitations associated with resins such as high back-pressure, low linear velocities and diffusional limitations. In the membrane, the convective flow significantly enhances mass transfer and large-size pores provide high accessibility even for viral particles. In addition, column packing and column testing are eliminated when using membrane absorbers or monoliths [10-12].

In the present work, the capture step for the purification process of the yellow fever virus from Vero cell culture supernatant was investigated. This is a critical step because the supernatant volume must be quickly reduced to concentrate, isolate and stabilize the antigen, transferring it to a buffer that will conserve potency/activity [6,13].

For the experiments a $\mathrm{Q}$ membrane adsorber was utilized. The best $\mathrm{pH}$ for viral stability and virus adsorption, the best salt concentration for elution and the dynamic binding capacity of the membrane were investigated.

\section{Materials and methods}

\subsection{YF virus production}

The YF virus suspension was produced in stirred bioreactors (BioFlo 110, New Brunswick Scientific, model M 1273-0054) fitted with a $3 \mathrm{~L}$ vessel ( $2.2 \mathrm{~L}$ working volume) at $37^{\circ} \mathrm{C}, 70 \mathrm{rpm}, \mathrm{pH}$ 7.2 and 50\% air saturation [3]. Vero cells (ECCAC) were grown on Cytodex 1 microcarriers (GE Healthcare) at a concentration of $3 \mathrm{~g} / \mathrm{L}$ in a serum-free medium supplemented with glutamine to $4 \mathrm{mM}$ final concentration (Gibco, Invitrogen Corp.) and Pluronic F68 to $0.01 \%(\mathrm{~m} / \mathrm{v}$ ) final concentration (Sigma Aldrich Co.). Infection was carried out on the 3rd day post-inoculation, using a multiplicity of infection (MOI) of 0.02 .

At the end of the process, the culture was decanted and subsequently clarified using Sartopure PP2 Mini Caps $(8.0 \mu \mathrm{m})$, Sartoclean CA $(3.0 \mu \mathrm{m}+0.8 \mu \mathrm{m})$ and Sartobran $\mathrm{P}(0.45 \mu \mathrm{m}+0.2 \mu \mathrm{m})$ filter units (Sartorius-Stedim).

\subsection{Analytical methods}

Quantification of total proteins was carried out using the BCA protein assay kit (Pierce ${ }^{\circledR}$ ) according to manufacturer's instructions.

DNA content was determined using Qubit ${ }^{\mathrm{TM}}$ Quantification Fluorometer (Invitrogen Corp.), according to the manufacturer's instructions.

HCP concentration was measured using a commercial Vero Cell HCP ELISA kit, according to the manufacturer's instructions.

YF virus was quantified by virus titration as described previously [14] and by an ELISA assay developed in house, which measures the virus envelope protein concentration, thus named 'specific protein' hereafter.

\subsection{Virus stability over a wide $\mathrm{pH}$ range for choice of the ion exchanger}

In order to choose the most suitable ion exchanger, experiments were carried out to define the $\mathrm{pH}$ range for best virus stability. The $\mathrm{pH}$ of the clarified virus suspension was adjusted with $3 \mathrm{M} \mathrm{HCl}$ or $1 \mathrm{M} \mathrm{NaOH}$ in the range of 4.5-9.0, with intervals of $0.5 \mathrm{pH}$ units and then incubated for $1 \mathrm{~h}$ at $25 \pm 5$ and $5 \pm 3^{\circ} \mathrm{C}$. The quantification of YF in each sample was performed by viral titer and this value was compared to the titer of the viral suspension without $\mathrm{pH}$ adjustment, incubated under identical conditions.

\subsection{Selection the best $\mathrm{pH}$ for virus adsorption}

The adsorption $\mathrm{pH}$ was selected through experiments within the stable range for the virus, where the amount of antigen adsorbed onto the membrane was quantified. With this purpose, a volume of $5 \mathrm{~mL}$ of virus suspension with $\mathrm{pH}$ previously adjusted to the range of 7.5-9.0 using $1 \mathrm{M} \mathrm{NaOH}$ was applied to a $\mathrm{Q}$ membrane adsorber with $75 \mathrm{~cm}^{2}$ nominal membrane area. Sample application was performed manually, using disposable syringes. The content of YF virus in the flow-through was quantified by ELISA and viral titer. This value was compared to the titer of the original virus suspension to quantify the percentage of antigen adsorbed.

\subsection{Optimization of chromatography operational conditions}

Chromatography experiments were performed using Akta Purifier 10, operated with the UNICORN software (GE Healthcare). The flow rate used was $10 \mathrm{~mL} / \mathrm{min}(122.3 \mathrm{~cm} / \mathrm{h})$, based on recommendations of the membrane manufacturer. Sanitization of the membrane adsorber was carried out with $50 \mathrm{~mL}$ of $1 \mathrm{M} \mathrm{NaOH}$ and equilibrium with the same volume of $0.05 \mathrm{M}$ Tris, $\mathrm{pH} 8.5$ (Amresco). The sample was kept in an ice bath prior to and during sample application.

The $\mathrm{pH}$ of the clarified virus suspension was adjusted to 8.5 with $1 \mathrm{M} \mathrm{NaOH}$ and then $200 \mathrm{~mL}$ were applied onto the membrane. Non-bound substances were washed out by applying $30 \mathrm{~mL}$ of the equilibrium buffer. In order to determine the best elution conditions, linear and step gradients were carried out by increasing $\mathrm{NaCl}$ concentration $(0-1 \mathrm{M})$ in $0.05 \mathrm{M}$ Tris buffer $\mathrm{pH}$ 8.5. Fractions were collected and analyzed for YF by ELISA.

Regeneration was performed with $0.05 \mathrm{M}$ Tris buffer containing $1 \mathrm{M} \mathrm{NaCl}, \mathrm{pH} 8.5$, followed by cleaning with $1 \mathrm{M} \mathrm{NaOH}$. After reequilibration, filters were rinsed with $20 \%$ ethanol containing $1 \mathrm{M}$ $\mathrm{KCl}$ prior to storage at $4^{\circ} \mathrm{C}$.

\subsection{Dynamic binding capacity}

The dynamic binding capacity was determined at linear velocities of $61.2,122.3$ and $244.6 \mathrm{~cm} / \mathrm{h}$, using Akta Purifier 10 and Akta Avant 150. To obtain the breakthrough curves for the Q membrane, 
(A)

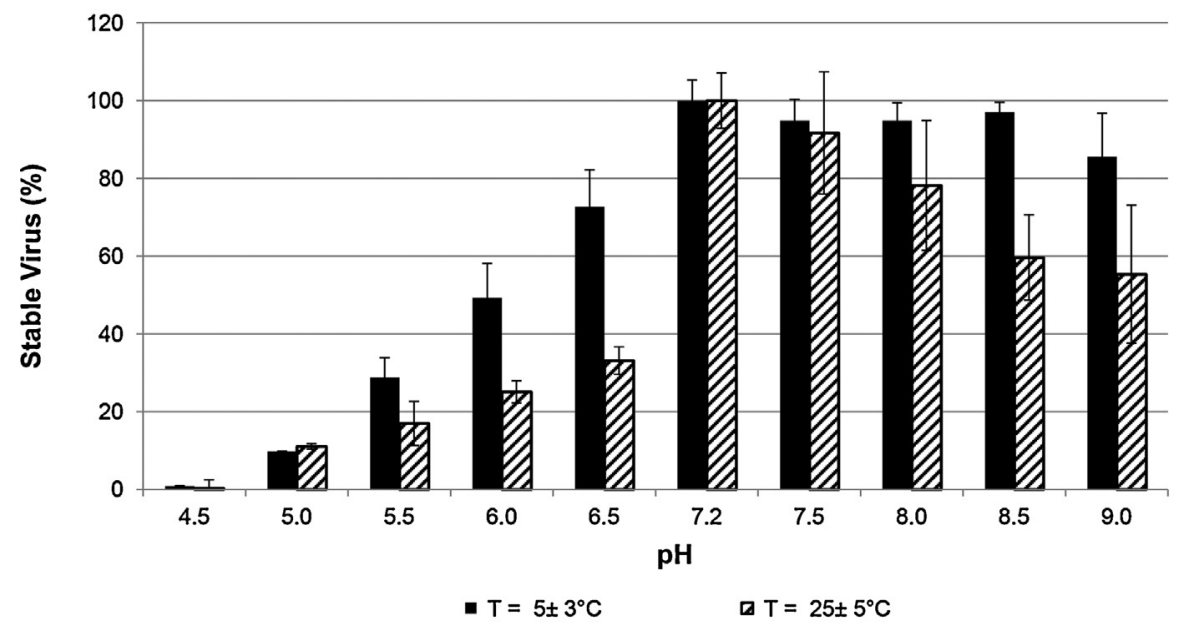

(B)

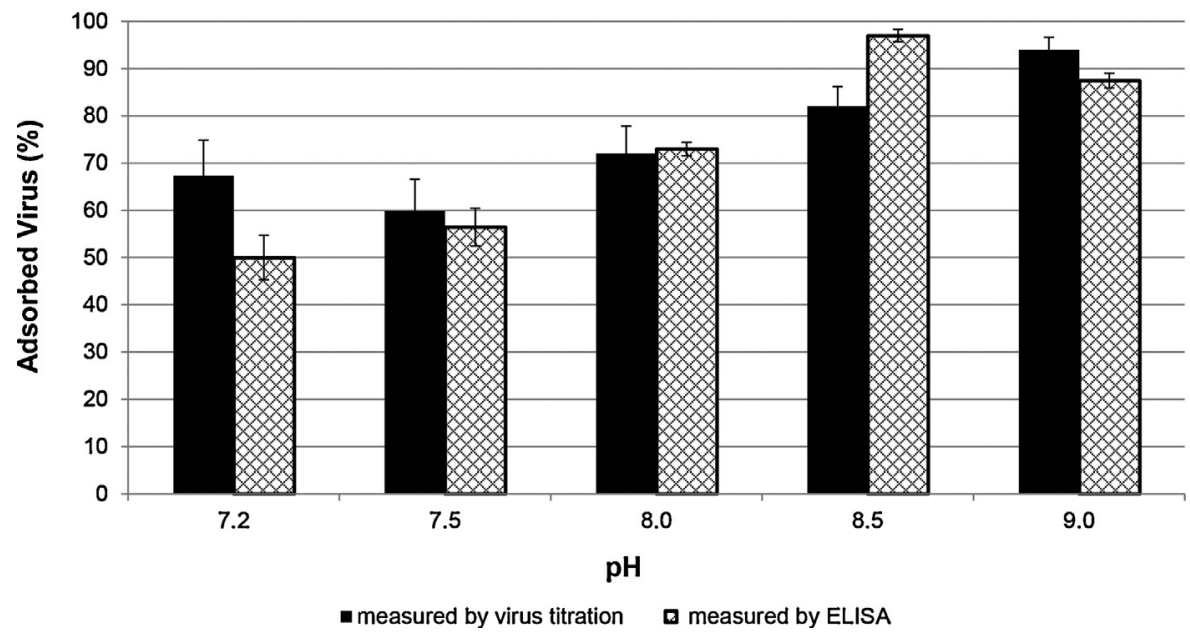

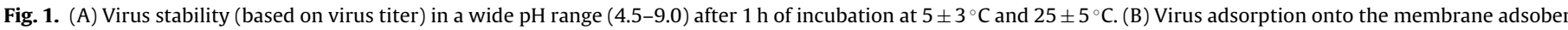

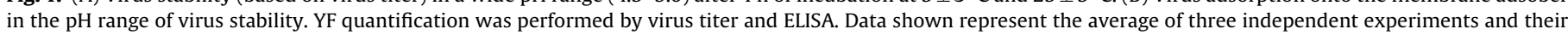
standard deviation.

the viral suspension was applied until the maximum working pressure of the membrane (0.6 MPa). Flow-through fractions were collected and analyzed by ELISA to determine the amount of specific protein adsorbed per membrane area.

\section{Results and discussion}

\subsection{Virus stability over a wide $\mathrm{pH}$ range}

Although the final aim of the work is to develop an inactivated vaccine from the attenuated YF strain, it was considered that monitoring virus stability by titration prior to the inactivation step and choosing operational conditions favoring virus stability would decrease the chances of affecting virus structure and consequently its immunogenicity.

Fig. 1A shows the percentage of stable virus, based on virus titer, in a pH range of $4.5-9.0$ after $1 \mathrm{~h}$ of incubation at $5 \pm 3{ }^{\circ} \mathrm{C}$ and $25 \pm 5^{\circ} \mathrm{C}$. The virus was unstable at $\mathrm{pH}$ values below to 6.5 , but in the neutral and alkaline region it was rather stable at the lower temperature $\left(5 \pm 3^{\circ} \mathrm{C}\right)$, with a decrease in titer being observed only at $\mathrm{pH}$ 9.0. However, at $25^{\circ} \mathrm{C}$ a decrease in titer was observed already at $\mathrm{pH}$ 8.0. These results confirm literature information stating that flaviviruses are optimally stable at $\mathrm{pH} 8.4-8.8$ and sensitive to acid $\mathrm{pH}[15]$.
The $\mathrm{pI}$ of the YF envelope protein had been previously determined in silico using ExPASy (Expert Protein Analysis System) to be approximately 6.38. Based on these results, the group exchanger $Q$ (quaternary ammonium) was chosen for the capture step, because within the virus stability range the $\mathrm{pH}$ could be set at least $1 \mathrm{pH}$ unit above the virus $\mathrm{pI}$, keeping the virus negatively charged to interact with the anion exchanger.

\subsection{Selection of $\mathrm{pH}$ for virus adsorption onto the $\mathrm{Q}$ membrane}

Virus adsorption onto the $\mathrm{Q}$ membrane was evaluated in the $\mathrm{pH}$ range of stability (7.5-9.0) by virus titer and ELISA (Fig. 1B). In this alkaline region the percentage of adsorbed virus increased with increasing $\mathrm{pH}$. However, due to virus stability, the $\mathrm{pH}$ of 8.5 was chosen for the adsorption step.

\subsection{Optimization of chromatography operational conditions}

In order to first determine the range of $\mathrm{NaCl}$ concentration where the virus elutes, chromatography runs were carried out both adopting linear gradient elution and step elution. The chromatographic profile under linear gradient elution is shown in Fig. 2A. The percentage of virus recovery in each fraction, quantified by ELISA, is also shown. The product of interest was eluted at a salt 

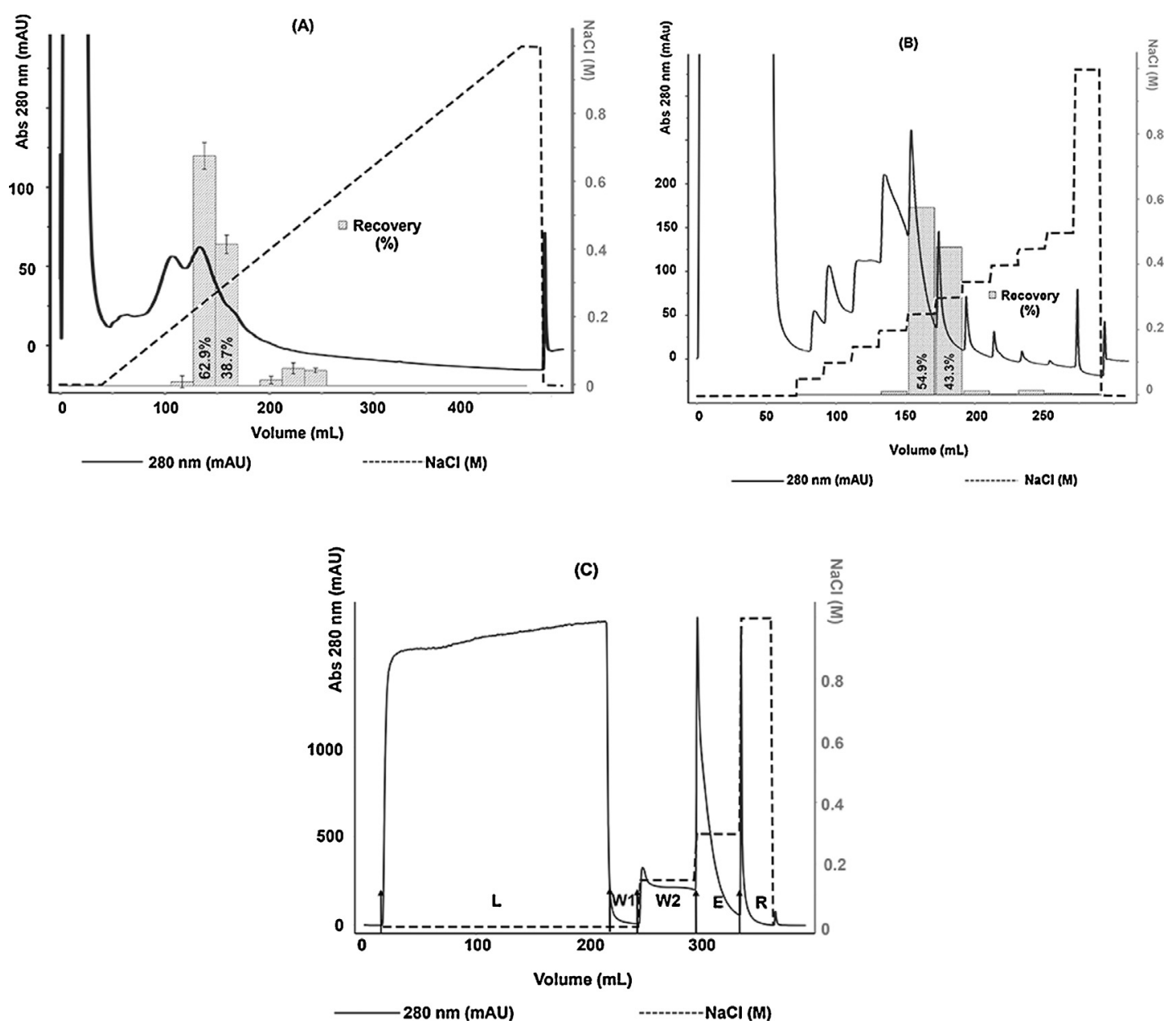

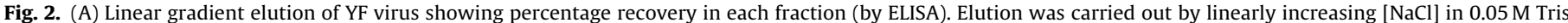

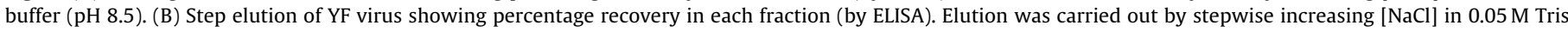

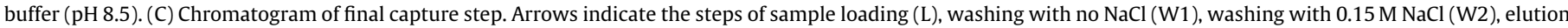
$(\mathrm{E})$ and regeneration $(\mathrm{R})$.

concentration around $0.25 \mathrm{M}$ to $0.30 \mathrm{M}$. This result was confirmed in the step gradient, shown in Fig. 2B. Furthermore, it was found that impurities are eluted at lower salt concentrations, where the presence of the product of interest was not detected. Therefore we concluded that washing with $0.15 \mathrm{M} \mathrm{NaCl}$ would be adequate for process performance. Based on these results, final process configuration was established to include a washing step at $0.15 \mathrm{M} \mathrm{NaCl}$ and elution at $0.3 \mathrm{M} \mathrm{NaCl}$.

A typical chromatogram for this final process is shown in Fig. 2C. Average yield of the product was $93.2 \pm 30.3 \%$ (by ELISA), which is in a similar range to that achieved in other studies also utilize ion exchangers for the purification of viral particles [7,12].

The DNA content in the eluted fraction was $0.9 \pm 0.3 \mathrm{ng} / \mathrm{dose}$, considering a dose established according to preliminary immunogenicity studies. This value is lower than required by regulatory agencies (10 ng/dose) [16].

Regarding host-cell protein impurities, although in literature a level of $100 \mathrm{ppm}$ (HCP per specific protein) is usually mentioned as maximum acceptable HCP concentration $[17,18]$, the limit yet to be defined by regulatory agencies will probably vary for different

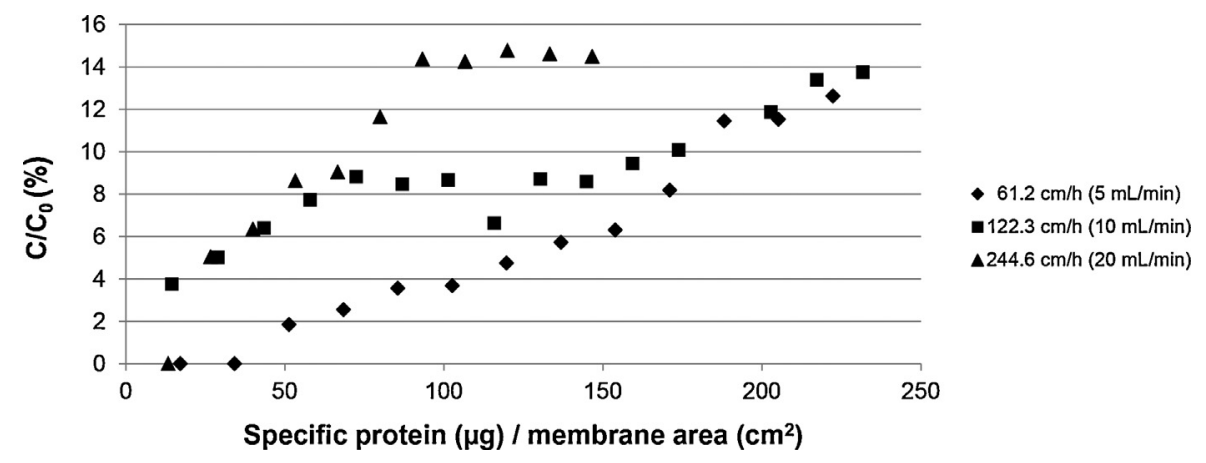

Fig. 3. Breakthrough curves obtained by applying clarified yellow fever virus suspension at three different linear velocities to $\mathrm{Q}$ membrane adsorber. 
vaccines and different biopharmaceuticals, because both the number of doses can vary significantly and the amount of specific protein in a final dose can be considerably different. In our study, the specific protein we quantified is the envelope protein of the YF virus and the relation of the concentration of this protein to the concentration of the final active ingredient is not known yet. Anyway, the level of host cell protein we obtained was considerably high (317,622 $\pm 97,969 \mathrm{ppm}$, or ng $\mathrm{HCP} / \mathrm{mg}$ specific protein), indicating the need for targeting HCP in a subsequent step.

\subsection{Dynamic binding capacity}

Fig. 3 shows breakthrough curves determined for the $Q$ membrane adsorber at different linear velocities. A small decrease in binding capacity can be observed with increasing linear velocity. Since this membrane has been used for a capture step, where speed is an important feature, a linear velocity $122.3 \mathrm{~cm} / \mathrm{h}$ was chosen for which at $10 \%$ breakthrough a dynamic capacity approximately $170 \mu \mathrm{g}$ of specific protein per membrane area $\left(\mathrm{cm}^{2}\right)$ was determined.

\section{Conclusions}

In this work, starting from the theoretical pI of the YF envelope protein and after determining virus stability as a function of $\mathrm{pH}$, a $Q$ anion-exchange membrane was chosen for the capture step of YF virus from Vero cell supernatant. Subsequently, adsorption tests enabled determination of the best $\mathrm{pH}$ for adsorption (8.5) and chromatography runs allowed determining the best type of elution (stepwise increase in $\mathrm{NaCl}$ concentration), as well as the best $\mathrm{NaCl}$ concentration for washing $(0.15 \mathrm{M})$ and elution $(0.3 \mathrm{M})$.

The data obtained in chromatographic runs under these conditions demonstrate that the $\mathrm{Q}$ membrane adsorber is a promising option for YF virus capture from cell culture supernatant in the large-scale process. High viral recovery was achieved (93\%) and eluted fractions already showed acceptable levels of DNA $(0.9 \mathrm{ng} /$ dose $)$. Furthermore, the membrane showed good dynamic capacity even for viral particles. Levels of the HCP remained above the limits, but could be targeted in a subsequent polishing stage.

\section{Conflicts of interest}

No conflicts of interest are declared.

\section{References}

[1] Monath TP, Lee CK, Julander JG, Brown A, Beasley DW, Watts DM, et al Inactivated yellow fever 17D vaccine: development and nonclinical safety, immunogenicity and protective activity. Vaccine 2010;28:3827-40.

[2] Gardner CL, Ryman KD. Yellow fever: a reemerging threat. Clinical Laboratory Medicine 2010;30:237-60.

[3] Souza MC, Freire MS, Schulze EA, Gaspar LP, Castilho LR. Production of yellow fever virus in microcarrier-based Vero cell cultures. Vaccine 2009;27:3420-6423.

[4] Conference report. 17D yellow fever vaccines: new insights. A report of a workshop held during the World Congress on medicine and health in the tropics, Marseille, France. Vaccine 2007;25:2758-65.

[5] Freire MS, Mann GF, Marchevsky RS, Yamamura AMY, Almeida LFC, Jabor AV, et al. Production of yellow fever 17DD vaccine virus in primary culture of chicken embryo fibroblasts: yields, thermo and genetic stability, attenuation and immunogenicity. Vaccine 2005;23:2501-12.

[6] Vicente T, Mota JPB, Peixoto C, Alves PM, Carrondo MJT. Rational design and optimization of downstream processes of virus particles for biopharmaceutical applications: current advances. Biotechnology Advances 2011;29: 869-78.

[7] Forcic D, Brgles M, Ivancic-Jelecki J, Šantak M, Halassy B, Barut M, et al. Concentration and purification of rubella virus using monolithic chromatographic support. Journal of Chromatography B 2011;879:981-6.

[8] Rodrigues T, Carrondo MJT, Alves PM, Cruz PE. Purification of retroviral vectors for clinical application: biological implications and technological challenges. Journal of Biotechnology 2007;127:520-41.

[9] Vicente T, Sousa MFQ, Peixoto C, Motab JPB, Alves PM, Carrondo MJT Anion-exchange membrane chromatography for purification of rotavirus-like particles. Journal of Membrane Science 2008;311:270-83.

[10] Czermak P, Grzenia DL, Wolf A, Carlson JO, Specht R, Han B, et al. Purification of the densonucleosis virus by tangential flow ultrafiltration and by ion exchange membranes. Desalination 2008;224:23-7.

[11] Vogel JH, Nguyen H, Giovannini R, Ignowski J, Garger S, Salgotra A, et al. A new large-scale manufacturing platform for complex biopharmaceuticals. Biotechnology and Bioengineering 2012;109(12):3049-58.

[12] Kalbfuss B, Wolff M, Geisler L, Tappe A, Wickramasinghe R, Thom V, et al. Direct capture of influenza A virus from cell culture supernatant with Sartobind anion-exchange membrane adsorbers. Journal of Membrane Science 2007;299:251-60.

[13] GE Healthcare strategies for protein purification handbook; 2010.

[14] Caufour PS, Motta MC, Yamamura AM, Vazquez S, Ferreira II, Jabor AV, et al. Construction, characterization and immunogenicity of recombinant yellow fever 17 D-dengue type 2 viruses. Virus Research 2001;79:1-14.

[15] Fields BN, Knipe DM, Howley PM. Fields virology. Fifth ed. Philadelphia: Wolters Kluwer Health/Lippincott Williams \& Wilkins; 2007.

[16] World Health Organization. WHO Study Group on cell substrates for production of biologicals. Geneva: WHO Headquarters; 2007.

[17] Wolter T, Richter A. Assays for controlling host-cell impurities in biopharmaceutical. Bioprocess International 2005; February.

[18] Champion K, Madden H, Dougherty J, Shacter E. Defining your product profile and maintaining control over it: Part 2. Challenges of monitoring host cell protein impurities. Bioprocess International 2005; September. 